\title{
CONVERGÊNCIA DE SABERES E CONHECIMENTOS DE ENFERMAGEM NO CUIDADO À FAMÍLIA
}

\author{
Convergence of nursing beliefs and knowledge in the family care \\ Convergencia de saberes y conocimientos de enfermería en el cuidado a la familia
}

Ĺgia Barros Costa

Maria Grasiela Teixera Barroso

Afańliatemsido prionizada por meio deprogramas sociais, emespedial, coma descentralizaçáo das ações desaúde Emdetrimerto das transformações ocoridas, contudo, estavisão voltada para o gnupo familiar continua atrelada a um paradigma biologicista, centrado na patologia, alimertando o sistema com dados epidemológicos pouco substanciais notocanteàs necessidades, condições de vida e saúde das famílias. O presente estudo emergiu da necessidade de se desenvolver e compartilhar conhecimentos que norteiem a atuação dos profissionais ematenção primária de saúde, coma fańlia oajpando o papel de sujeito ativo na busca de resolução de problemas, numa dimensão de co-responsabilidade e cidadania. Buscourseresponder às seguintes questôes: cono as enfermeras têmaplicado os marcos teóricos no cotidiano da prática da Enfermagem com famílias? Que saberes produzidos convergeme expressama tendêndia teórico-prática do cuidado deenfermagemàfamília? Para tanto, objejivourse descolorir a tendêndia teórico-prática do cuidado de enfermagem com famílias, a partir da convergência do saber popular e do corhecimento acadêrico. Gotourse pelo método qualitativo de pesquisa, utilizando a modalidade convergenteassistencial. Os participantes do estudo compreenderam14 enfermeros, dentre os quais sete representarama atividade de pesquisa e sete a prática assistendal. Dentreos querepresentaram a pesquisa, quatro encontravamse no nível de Dautorado e três no de Mestrado. Por sua vez, os enfermeiros da prática compreenderam duas supervisoras de campo e cinco ex-alunos, representando o estágio supenisionado, por meio da monografia de graduação. Efetivoutse a abordagem aos participantes por intermédio de duas etapas, sendo a primeira mediante contato indvidual e a segunda, priorizando a construção coletiva da realidade. Foramudilizados questionánios e se solicitou una cópia das teses e dissertacões paraleituradinigida por umroteiro estruturado. Para segunda etapa, empregourse a técrica de paind interativo, tendo sido validados os marcos conceituais do aidado com famílias em atenção primária Aconvergênáa dos saberes foi apresentada segundo os padróes de corhecimento - empíico, ético, pessoal e estético, de Chim e Kramer' ${ }^{-1}$ e sócio-político, deWWite'. Os padrões deconhedimerto éticoeestético encontraramseevíguos, emrelação a uma declaração explícita deles, pelos pesquisadores partíipantes do estudo. Utmavezque o padrão ético estevepresenteemapenas dois dos sete trabalhos analisados, oferece, portanto, uma lacuna para estudos posteriores, por se tratar do componente moral de tomada de decisões pelo enfermeiro. Como propósito, construitse umguia prático para uitilização no aidado comfamílias em atenção primária, na perspectiva de sugerir a enfermeiros e estudantes da Enfermagem uma ferramenta para adoção de uma postura reflevivocútica diartedo aidado humano. Considerar-seque o saber popular e o corhedimento acadênico são convergentes, estão integrados e integrando o cuidado de Enfermageme respondema demanda de atenção primária de saúde das famílias.

Palaraschave Enfermagem SaúdedaFamia Atenção Prinániaà Saúde 
Thefanily has been prioritized through social prograns, especially with the decertralization of health adtions. However, to the detriment of the transformaions happened, this glance directed to the family grap continues linked to a biological paradigm, certered in the pathology, feeding the systemwith epidemidogical data, not substantial concerming the real needs, life conditions and health of the families. The presert study energed from the need of developing and sharing knowedgethat orientatetheprofessional' performance inprimaryattertion of health, with thefamily playing therole of adive subject in thesearch of solution for problens, in a co-responsibility and ditzenship dimension We aimed to answer the following questions: Howheve nurses been applying the theoreticd marks in the daily pradice of Nursing with fanilies? Wich knowledge produced converges andexpresses thetheoretical-pradical tendency of Nursing care to the farily? For doing so we aimed to reved the theoredcal-practical tendency of the Nursing care with families, starting from theconvergence of popular andacademic knowedge Weopted for the qualitaive research method, using the convergent-dinical mocblity. The participants of thestudy were 14 nurses, amongwich 07 represented the research advity and 07 represented thedinical pradice Arrong the ones who represented the research, 04 were in theDoctortelevel and03 in the Mester's degree Ontheotherhand, thenurses of the pradice were 02 field supenisors and 05 formerstudents, representing the supenised apprenticeship, through the graduation monograph We exeated the approach to the participarts through tho stages, being the first, by indvidul contad and the second, prioritizing the colledive construction of reality. We used questiomaires, and requested a copy of the theses and dissertations for directed reading by structured handout. For the second stage, we used the interadive pand tedrique, where the conceptual marks of care with families in primary attention were validated. The convergence of the knowedge was presented according to the knowedge pattems (empinical, ethical, personal andaesthetic) of Chimand Kramer ${ }^{-1}$ and (socio-politica) of Wite? . Fromthese, theethical andaesthetic patterns were afews in relation to an explicit dedaration of these, by the participant researchers of thestudy. Oncetheethical pattem was present in only two of the seven works analyzed, it offers, therefore, a gap for subsequent studies, for being the moral component of decision making by the nurse As purpose, webuilta pradical guideto be used in thecare of families in primaryattention, in the perspective of suggesting to nurses and Nursing students, a tool for the adoption of a reflexive critic posturebeforethehumancare Weconsidered that thepopular knowedge and the acaderic knowedge are convergent, are integrated and integrate the Nursing careand answer thefamilies' need for primary attention of health
La familia ha sido priorizada por medio de programas sociales, en especial, con la descentralización de las acciones de salud. En detrimento de los cantios ocumidbs, sin enbargo, esta visión se Ĺgia Barros Costa se vulve para el grupo faniliar continúa asociada a un peradigma biologicista centrado en la patología, alimentando el siste ma con datos epideridógicos, poco substanciales en el tocartea las necesidades, condiciones de vida y salud de las familias. E presente estudio emergió de la necesidad de desarrollarse y compartir conodimientos que orienten para la actuación de los profesiondes en atencón primariadesalud, conlafamiliacapandb lafundóndesujeto adivo en la búsqueda de resolución de problemas, en una dimensión decoresponsabalidadyciudadaría Sebuscaresponder alassiguientes austiones: Comm las enfermeras han aplicado los marcos teónicos en el cotidiano de la prádica de Enfermería con familias? Qe saberes producidos tienden yexpresan latendenciateórico-prádica del aidado de Erfermería a la familia? Por lo tanto, se objetiva desaubrir la tendencia teórico-prádica del aidado de Enfermería con familias, a partir de la convergencia del saber popular y del conocimiento acadénico. Segptó por a métodb a litativo dein vestigacón, uilizando la modalidad convergente-asistendal. Los participartes del estudio comprendieron 14 enfermeros, entre los a ales 07 representaron la adtividad de investigación y 07 la prádica asistendal. Entre los que representaron la investigacón, 04 se encontraban en el nivel de Dodtorado y 03 en el de Méster. Por su parte, los enfermeros de la prádica comprendieron 02 supenisoras decampo y 05 ex-alumos, representandola prádicasupenisada, por medio dela monografíade pregrado. Se efectivó el abordaje a los participantes por intermedio de dos etapas, siendb la primera medarte contado individual y la segunda, priorizando la construccón colectiva de la realidad Fueron utilizados arestionarios, y se solicitó una copia de las tesis y disertaciones para lectura dirigida por un gión estruturado. Parala segunda etapa, se empleó la técrica de pand interactivo, habiendo sido validados los marcos conceptudes del aidadb con familias en atendónprimaria Laconvergenciadelos saberesfuepresentadasegín los patrones de conocimiento (emṕíico, ético, personal yestético) de Chim y Kramer y (socio-político) de Witer. De estos, los patrones ético yestético seencontraron exiguos, en relacióna una dedaración explíita de ellos, por los investigadores participantes del estudio. Una vez quee patrónético estuno presenteen sólo dos delos siete trabajos analizados, ofrece, por lo tanto, un espacio para estudios posteriores, por tratarse del componente moral de toma de dedisiones por el enfermero. Como propósito, seconstruyó unguía prádico para utilizacónen el aidado confamilias en atencón primaria, en la perspectiva de sugerir a enfermeros y estudiantes de Enfermería na herramienta paraadopción deuna postura reflexivoática delante del aidado humano. Seconsideró que el saber popur laryel conocimiento académico son convergentes, están integrados eirtegrando el aidado de Enfermería y responden a la demanda de atencón primaria desalud de las familias.
Keymords
Nursing. FamilyHealth. Prinary Health Care
Palabras dave

Efermería. Salud dela Familia. Atencón PrinzriadeSalud. 


\section{Referências}

1. ChimPL, Kramer MK Theoryand Nursing: asystemapproach. St. Louis(Mssour): Mbsby, 1995.

2. WiteJ. Pattems of knowing: review critiqueand update Adlanced Nursing Science 1995; 17(4): 73-86.

\section{Sobre as Autoras}

\section{Ĺgía Barros Costa}

ProfessoraAdjuntoIVdoProgramadePós-GraduaçãoemEnfermagem do Departamento de Enfermagem da Faculdade de Farmácia, OontologiaeEnfermagemda U hiversidadeFederal do Ceará Doutora enErfernagem CoordenadoradoCentro de DesenvolvimentoFaniliar (CH)EAM/ PREX/ UFO). ligiabcosta@zipmail.combr

\section{Maria Gasida Teisira Barroso}

ProfessoraEnérita da UniversidadeFederal do Cearáedo Programa de Pós-Graduação em Enfermagemda Fauldade de Farmácia, Codontologia e Evfermagem Oientadora. Doutora e Live Docente pelaUFC grasiela@ufc.br 